\section{Changing biodiversity scenario in the Himalayan ecosystem: Mussoorie, Uttarakhand, India, as revealed by the study of blue butterflies (Lycaenidae)}

\section{Avtar Kaur Sidhu}

High Altitude Regional Centre, Zoological Survey of India, Saproon, Solan, Himachal Pradesh 173211, India

Email: avtarkaur2000@rediffmail.com

An area rich in biodiversity is of great importance for conservation. Butterflies form an important component of biodiversity. Apart from their aesthetic appeal, they are good pollinators. As butterflies are highly sensitive to any environmental change and are delicate creatures, they act as good bio-indicators of the health of a habitat. However these creatures are under a real threat due to various developmental activities leading to habitat changes. The protection of these creatures should be given priority. Since the conservation of butterflies essentially means the conservation of their habitat, the spots rich in butterfly diversity are high conservation priority areas.

In general, areas with undisturbed vegetation and highfloral diversity supportlarge butterfly communities. Few places in India can rival the abundance, both in

Date of publication (online): 26 February 2011

Date of publication (print): 26 February 2011

ISSN 0974-7907 (online) | 0974-7893 (print)

Editor: Peter Smetacek

Manuscript details:

Ms \# o2349

Received 20 November 2009

Final received 05 May 2010

Finally accepted 17 January 2011

Citation: Sidhu, A.K. (2011). Changing biodiversity scenario in the Himalayan ecosystem: Mussoorie, Uttarakhand, India, as revealed by the study of blue butterflies (Lycaenidae). Journal of Threatened Taxa 3(2): 1559-1563

Copyright: (C) Avtar Kaur Sidhu 2011. Creative Commons Attribution 3.0 Unported License. JoTT allows unrestricted use of this article in any medium for non-profit purposes, reproduction and distribution by providing adequate credit to the authors and the source of publication.

Acknowledgements: The author is thankful to the editor for critically scrutinizing the manuscript besides giving useful suggestions in improving it. Thanks are also due to Director, Zoological Survey of India, Kolkata for giving research facilities and financial assistance to undertake these studies.

\section{OPEN ACCESS | FREE DOWNLOAD (C) (1) ৫)}

terms of species and sheer numbers of individuals, of butterflies as found in Mussoorie. Mussoorie is located at $30^{\circ} 27^{\prime} \mathrm{N}$ and $78^{\circ} 5^{\prime} \mathrm{E}$ in the Garhwal Hills and is known as the 'Queen of Hills' for its immense natural beauty. In 1820, Captain Young was enchanted by its beauty and made it his home. Mussoorie is named after the Mansur shrub, which used to grow in abundance here. Mussoorie is at a height of $2112 \mathrm{~m}$. It is rich in flora and fauna.

Mackinnon \& de Nicéville (1897), Ollenbach (1929), Shull (1958, 1962), and Rose \& Sidhu (1994) made checklists of butterflies of Mussoorie and reported it as one of the richest areas in butterfly diversity. But due to excessive tourism coupled with various developmental activities, this hill station in recent times has undergone severe environmental degradation. In the present paper, a checklist of 66 species of lycaenid butterflies of Mussoorie, Uttarakhand has been prepared and compared with the lists made by the above mentioned earlier workers (Table 1). The nomenclature for naming various taxa, has been followed from Bridges (1988) and Varshney (1997).

\section{Material and Methods}

A literature search resulted in the collation of the various lists mentioned above. Mussoorie was visited by the author from June 2005 to September 2006. During this period, a total of 25 days was spent observing butterflies in the area. During these visits, 38 species of butterflies were recorded (Sidhu \& Narender 2010). These specimens are presently in the collection of the Zoological Survey of India, Kolkata.

\section{Observations and Discussion}

The checklist of lycaenid butterflies has been made from the collections made by different Zoological Survey of India workers between 2000 and 2006. The observations and studies were made in Mussoorie in the first week of June 2006 and again in September 2006 in areas like Bhilaru Pumping Station $\left(30^{0} 28.068^{\prime} \mathrm{N}\right.$ and $\left.78^{\circ} 04.095^{\prime} \mathrm{E}\right)$, one of the richest butterfly spots in India (located at 1737.4m) (Ollenbach 1929).

While listing butterflies of Mussoorie, Mackinnon and de Nicéville (1897) reported 316 species of butterflies from Mussoorie and its neighbouring 
Table 1. Checklist of lycaenid butterflies of Mussoorie, Uttarakhand

\begin{tabular}{|c|c|c|c|c|c|c|}
\hline & Species of Lycaenidae & $\begin{array}{c}\text { Ollenbach } \\
\text { (1929) }\end{array}$ & $\begin{array}{c}\text { Shull } \\
\text { (1962) }\end{array}$ & $\begin{array}{l}\text { Rose \& } \\
\text { Sidhu } \\
(1994)\end{array}$ & $\begin{array}{l}\text { In Uttarakhand other } \\
\text { than Mussoorie } \\
(2000-2006)\end{array}$ & $\begin{array}{c}\text { In Mussoorie } \\
\text { (Presently 2005- } \\
\text { 2006) }\end{array}$ \\
\hline 1. & Curetis bulis (Westwood) & + & - & - & - & - \\
\hline 2. & Horaga albimacula viola Moore & - & - & - & + & - \\
\hline 3. & Horaga onyx (Moore) & + & - & - & + & - \\
\hline 4. & Chrysozephyrus ataxus (Westwood) & + & - & + & + & - \\
\hline 5. & Chrysozephyrus birupa (Moore) & + & - & + & - & - \\
\hline 6. & Chrysozephyrus syla (Kollar) & - & + & - & - & - \\
\hline 7. & Esakiozephyrus icana (Moore) & + & - & - & - & - \\
\hline 8. & Eusapa ziha (Hewitson) & - & + & + & - & - \\
\hline 9. & Euaspa milionia (Hewitson) & + & + & + & - & - \\
\hline 10. & Chaetoprocta odata (Hewitson) & + & + & + & + & - \\
\hline 11. & Spindasis vulcanus (Fabricius) & + & - & - & + & - \\
\hline 12. & Spindasis nipalicus (Moore) & + & + & - & - & - \\
\hline 13. & Iraota timoleon (Stoll) & + & - & - & - & - \\
\hline 14. & Surendra vivarna (Horsfield) & + & - & - & - & - \\
\hline 15. & Arhopala pseudocentaurus (Doubleday) & + & - & - & - & - \\
\hline 16. & Arhopala rama (Kollar) & + & + & + & - & - \\
\hline 17. & Arhopala dodonaea (Moore) & + & + & + & - & - \\
\hline 18. & Arhopala atrax (Hewitson) & + & - & - & - & - \\
\hline 19. & Arhopala amantes (Hewitson) & - & + & - & + & - \\
\hline 20. & Panchala ganesa (Moore) & + & + & + & - & - \\
\hline 21. & Deudorix epijarbas (Moore) & + & - & + & + & - \\
\hline 22. & Deudorix isocrates (Fabricius) & + & - & - & - & - \\
\hline 23. & Deudorix perse (Hewitson) & + & - & - & - & - \\
\hline 24. & Rapala selira (Moore) & + & + & - & + & - \\
\hline 25. & Rapala nissa (Kollar) & + & + & + & + & - \\
\hline 26. & Rapala manea schistacea (Moore) & + & - & + & - & - \\
\hline 27. & Rapala iarbus (Fabricius) & + & - & - & - & - \\
\hline 28. & Tajuria diaeus (Hewitson) & + & - & - & - & - \\
\hline 29. & Tajuria illurgis (Hewitson) & + & - & - & - & - \\
\hline 30. & Loxura atymnus (Cramer) & + & - & - & - & - \\
\hline 31. & Pratapa icetas (Hewitson) & - & + & + & - & - \\
\hline 32. & Pratapa ctesia (Hewitson) & - & - & + & - & - \\
\hline 33. & Lycaena pavana (Westwood) & - & + & + & + & - \\
\hline 34. & Lycaena phlaeas (Linnaeus) & - & + & + & + & - \\
\hline 35. & Heliophorus androcles (Westwood) & - & - & + & - & - \\
\hline 36. & Heliophorus sena (Kollar) & + & + & + & + & - \\
\hline 37. & Heliophorus oda (Hewitson) & - & - & - & + & - \\
\hline 38. & Udara albocaerulea (Moore) & + & - & - & - & - \\
\hline 39. & Celastrina argiolus (Linnaeus) & + & - & + & + & + \\
\hline 40. & Celastrina huegelii (Moore) & + & + & + & + & + \\
\hline 41. & Celastrina gigas (Hemming) & - & - & + & + & - \\
\hline 42. & Acytolepis puspa (Horsfield) & + & + & - & + & - \\
\hline 43. & Celatoxia marginata (de Nicéville) & - & - & + & + & - \\
\hline 44. & Arletta vardhana (Moore) & - & + & - & - & - \\
\hline 45. & Chilades lajus (Cramer) & + & + & + & + & - \\
\hline 46. & Chilades pandava (Horsfield) & - & - & + & + & - \\
\hline 47. & Catochrysops strabo (Fabricius) & + & - & - & + & - \\
\hline
\end{tabular}




\begin{tabular}{|c|c|c|c|c|c|c|}
\hline & Species of Lycaenidae & $\begin{array}{l}\text { Ollenbach } \\
\text { (1929) }\end{array}$ & $\begin{array}{l}\text { Shull } \\
(1962)\end{array}$ & $\begin{array}{l}\text { Rose \& } \\
\text { Sidhu } \\
(1994)\end{array}$ & $\begin{array}{l}\text { In Uttarakhand other } \\
\text { than Mussoorie } \\
(2000-2006)\end{array}$ & $\begin{array}{c}\text { In Mussoorie } \\
\text { (Presently 2005- } \\
\text { 2006) }\end{array}$ \\
\hline 48. & Castalius rosimon (Fabricius) & + & - & - & + & - \\
\hline 49. & Lampides boeticus (Linnaeus) & + & + & + & + & + \\
\hline 50. & Aricia agestis (Denis \& Schiffermüller) & - & + & + & + & - \\
\hline 51. & Zizina otis (Fabricius) & - & + & - & + & - \\
\hline 52. & Zizeeria karsandra (Moore) & - & - & + & - & - \\
\hline 53. & Zizula hylax (Fabricius) & - & - & - & + & - \\
\hline 54. & Pseudozizeeria maha (Kollar) & - & - & + & + & - \\
\hline 55. & Everes argiades (Pallas) & - & - & + & + & - \\
\hline 56. & Everes lacturnus (Godart) & - & - & - & + & - \\
\hline 57. & Everes huegelii (Gistel) & - & - & + & + & + \\
\hline 58. & Jamides bochus (Stoll) & - & + & - & - & - \\
\hline 59. & Tarucus hazara Evans & - & - & - & + & - \\
\hline 60. & Tarucus alteratus Moore & - & - & - & + & - \\
\hline 61. & Leptotes plinius (Fabricius) & - & - & + & + & - \\
\hline 62. & Azanus ubaldus (Stoll) & - & - & - & + & - \\
\hline 63. & Prosotas nora ardates (Moore) & - & - & + & + & - \\
\hline 64. & Euchrysops cnejus (Fabricius) & - & - & - & + & - \\
\hline 65. & Freyeria putli (Kollar) & - & - & + & + & - \\
\hline 66. & Freyeria trochylus (Freyer) & - & + & + & + & - \\
\hline
\end{tabular}

areas. Ollenbach (1929) while listing 144 species of butterflies, described in detail the butterfly-rich spots of Mussoorie. It includes the Electric Pumping Station (1671.5m); Mossy Falls (1676.2m); Bhilaru Pumping Station; a spring on the eastern slope of Vincent's Hill (1981.2m) and a spring on the eastern side of the Kincraig Estate $(1706.9 \mathrm{~m})$. While describing the pumping station spots, Ollenbach (1929) reported, "In my collection trips throughout India, Burma and the Andaman Islands, I have come across places where butterflies were to be seen in large numbers, but these could not approach the multitudes that visit the pumping station". Shull (1958) reported 68 species from Mussoorie. Subsequently, Shull (1962) published a paper on butterflies of Mussoorie in which he reported five persons with nets catching 101 species in a single day (03 June 1961), the majority of them from Bhilaru Pumping Station and a few from the Municipal Park. On that day, 26 species of lycaenids were recorded, mostly from Bhimaru Pumping Station. These species are compared with the lycaenids recorded in the same location in June and September 2006, when only four of these species were recorded (Table 2). According to Shull (1962), "The hill station of Mussoorie in north-west India is probably one of the best places in the world for collecting a large number of species".
Rose \& Sidhu (1994) while listing the 34 species of lycaenid butterflies from Mussoorie collected from different spots, namely, Bhilaru Pumping Station, Murray Pumping Station, Mossy Falls, Savoy Hotel and Municipal Park in the first weeks of June 1992 and 1993, commented on the state of butterfly rich spots of Mussoorie reported by Ollenbach (1929) and Shull (1962). They observed that the springs on the eastern slope of Vincent's Hill (Image 1) and on east of the Kincraig Estate have dried up due to urbanization and other developmental activities; Mossy Falls was not very rich in butterfly species diversity but the Murray Pumping Station was comparatively better. According to Shull (1962) and Rose \& Sidhu (1994), the Bhilaru Pumping Station is the richest in butterfly species diversity as well as in number of individuals. Rose \& Sidhu (1994) commented that the butterfly habitat around Bhilaru Pumping Station was shrinking and needed to be effectively conserved. They also added that this spot was being contaminated and was stinking due to sewage effluents, besides blocking of water flow by the accumulation of waste, mainly polythene bags. H.S. Rose, who was a member of the party during the 1992-1993 visits (Rose \& Sidhu 1994) to various butterfly collecting spots in Mussoorie, had observed that a fairly large number of individuals belonging to a 
Table 2. List of lycaenids recorded from Bhilaru Pumping Station in a single day by Schull (1962) and the present survey between 2005 and 2006

\begin{tabular}{|l|l|c|c|}
\hline & Species of Lycaenidae & $\begin{array}{c}\text { In Mussoorie } \\
\text { (Presently } \\
\text { 2005-2006) }\end{array}$ & $\begin{array}{c}\text { Shull } \\
(1962)\end{array}$ \\
\hline 1. & Chrysozephyrus syla (Kollar) & - & + \\
\hline 2. & Eusapa ziha (Hewitson) & - & + \\
\hline 3. & Euaspa milionia (Hewitson) & - & + \\
\hline 4. & Chaetoprocta odata (Hewitson) & - & + \\
\hline 5. & Spindasis nipalicus (Moore) & - & + \\
\hline 6. & Arhopala rama (Kollar) & - & + \\
\hline 7. & Arhopala dodonaea (Moore) & - & + \\
\hline 8. & Arhopala amantes (Hewitson) & - & + \\
\hline 9. & Panchala ganesa (Moore) & - & + \\
\hline 10. & Rapala selira (Moore) & - & + \\
\hline 11. & Rapala nissa (Kollar) & - & + \\
\hline 12. & Pratapa icetas (Hewitson) & - & + \\
\hline 13. & Lycaena pavana (Westwood) & - & + \\
\hline 14. & Lycaena phlaeas (Linnaeus) & - & + \\
\hline 15. & Heliophorus sena (Kollar) & - & + \\
\hline 16. & Celastrina argiolus (Linnaeus) & + & - \\
\hline 17. & Celastrina huegelii (Moore) & + & + \\
\hline 18. & Acytolepis puspa (Horsfield) & - & + \\
\hline 19. & Arletta vardhana (Moore) & - & + \\
\hline 20. & Chilades lajus (Cramer) & - & + \\
\hline 21. & Lampides boeticus (Linnaeus) & + & + \\
\hline 22. & $\begin{array}{l}\text { Aricia agestis (Denis \& } \\
\text { Schiffermüller) }\end{array}$ & - & + \\
\hline 23. & Zizina otis (Fabricius) & - & + \\
\hline 24. & Everes huegelii (Gistel) & + & - \\
\hline 25. & Jamides bochus (Stoll) & - & + \\
\hline 26. & Freyeria trochylus (Freyer) & - & + \\
\hline & & & \\
\hline
\end{tabular}

variety of species were seen engaged in mud-puddling near the spring of Bhilaru Pumping Station from 0930 to $1400 \mathrm{hr}$ and the spot was full of butterflies (Images $2 \& 3)$.

In the first week of June, 2006 and again in the second week of September, 2006, the Bhilaru Pumping Station, was visited by the present author. This spot was on the outskirts of Bhilaru Village in 1993 and a narrow unpaved foot path connected it to the main Mussoorie road. But now the spot has been totally devastated from the point of view of butterfly habitats. Bhilaru Village has expanded. The spring has dried up (Image 4). The paved road has been built up to the Pumping Station. Bordering the favourite butterfly spot, shops have been built and are conducting business (Image 5). Only four species viz., Celastrina argiolus,

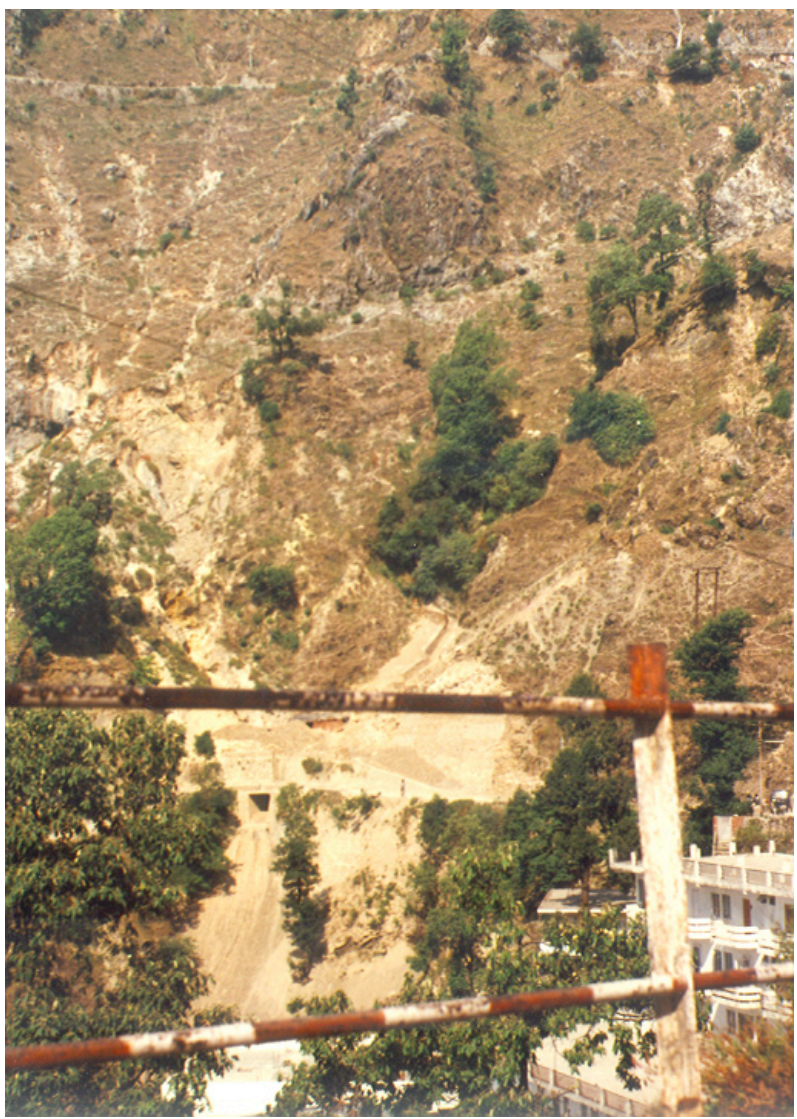

Image 1. Vincents Hills Spring, Mussoorie 1994

Celastrina huegelli, Everes huegelli and Lampides boeticus could be collected from this spot.

Keeping in view the richness of the butterfly diversity of this spot noted by previous workers, it is brought to the notice of concerned authorities that these butterfly rich spots should be conserved on a priority basis or else the provisions of the Wildlife (Protection) Act, 1972 will be meaningless, for while many of the wildlife species that inhabit the vicinity of Bhilaru Pumping Station are protected under provisions of the Act, the extermination of entire populations of these species is being countenanced in the ongoing developmental activities in the area and a unique heritage site is being lost due to ignorance on the part of the authorities, despite being well recorded in the literature (Mackinnon \& de Nicéville 1897; Ollenbach 1929; Schull 1962; Rose \& Sidhu 1994). Mussoorie and especially the vicinity of Bhilaru Pumping Station, being a good habitat for a great variety of butterflies in particular and biodiversity in general, must be given special status and care for conservation. This will also ensure a pure drinking water supply for Mussoorie in the years to come. 


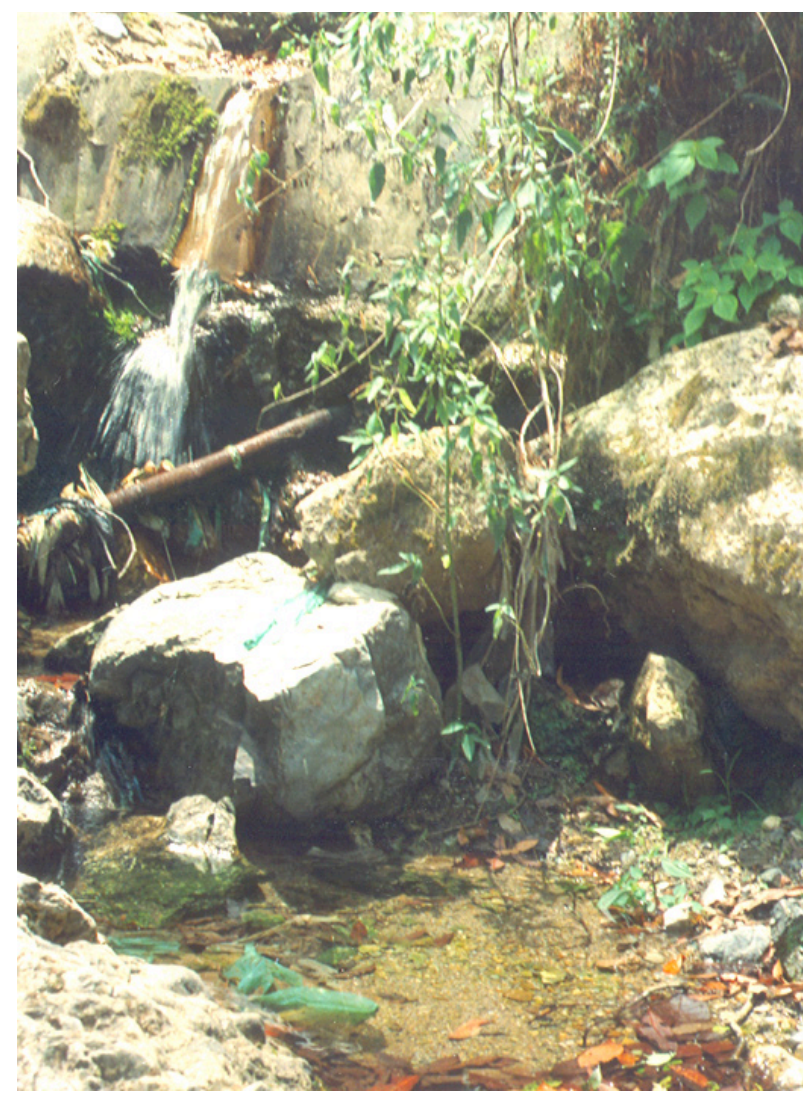

Image 2. Bhilaru Pumping Station spring, Mussoorie, 1994

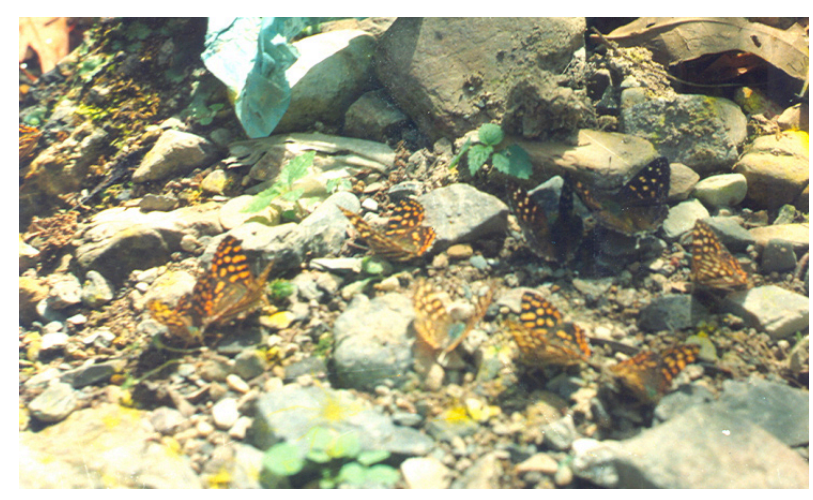

Image 3. Butterflies mud-puddling site close to Bhilaru Pumping Station spring, 1994

\section{REFERENCES}

Bridges, C.A. (1988). Catalogue of Lycaenidae \& Riodinidae (Lepidoptera : Rhopalocera). U.S.A. Lincoln Bookbindry, Urbana, Illinois, published by Charles A. Bridges: vii+ $($ I.ii + I.377) + (II.ii + II.115) + (III.ii + III.140) + (IV.ii + IV.101) + (V.ii+V.37) + (V.ii + VI.12) + Appen. I \& II.

Mackinnon, P.W. and L. de Nicéville (1897). A list of butterflies of Mussoorie in the western Himalayas and neighbouring region. Journal of the Bombay Natural History Society 11: 205-221; 368-389; 585-605.

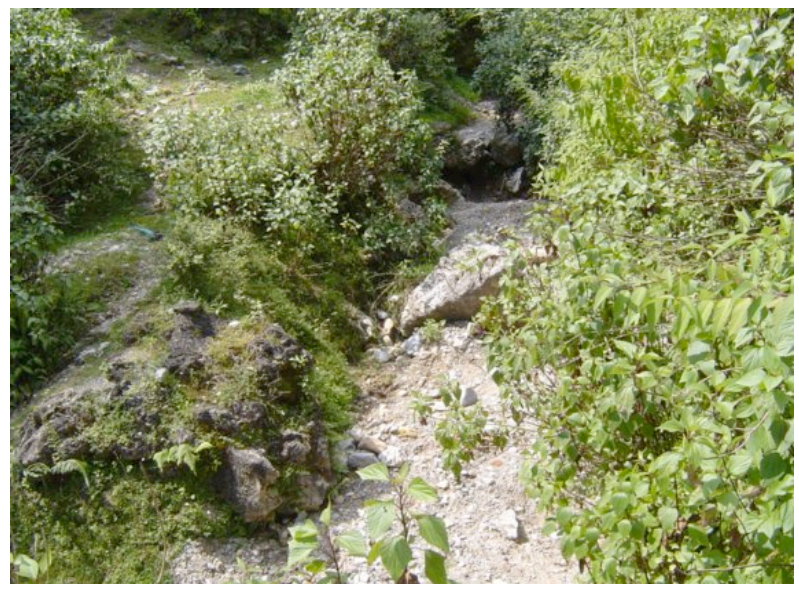

Image 4. Dried up Bhilaru Puming Station spring, Mussoorie, 2006

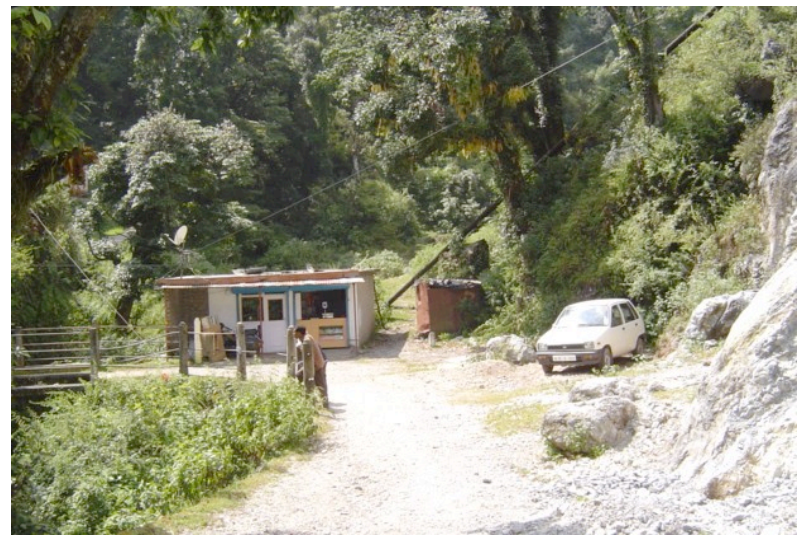

Image 5. Shops bordering Bhilaru Pumping Station spring Mussoorie, 2006

Ollenbach, O.C. (1929). Butterfly collecting grounds at Mussoorie. Journal of the Bombay Natural History Society 34 : 836-840.

Rose, H.S. \& A.K. Sidhu (1994). Lycaenid butterfly diversity of Mussoorie (Uttar Pradesh) along with some comments on Wildlife (Protection) Act, 1972. Cheetal 33(3-4): 10-16.

Shull, E.M. (1958). My highest catch of butterfly species in a single day ( $4^{\text {th }}$ June, 1957) Mussoorie, India. Journal of the Lepidopterists'Society $11: 167-168$.

Shull, E.M. (1962). Over one hundred butterfly species caught in a single day ( $3^{\text {rd }}$ June, 1961) at Mussoorie, India. Journal of the Lepidopterists' Society 16 : 143-145.

Sidhu, A.K. \& N. Sharma (2010). Insecta: Lepidoptera: Lycaenidae, Libytheidae and Acraeidae: Fauna of Uttarakhand, State fauna Series, Zoological Survey of India 18(Part-2) :531-552.

Varshney, R.K. (1997). Index Rhoplocera Indica Pt III. Genera of butterflies from India and neighbouring countries [Lepidoptera: (C) Lycaenidae]. Oriental Insects 31: 83138.

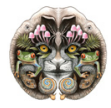

